\title{
Bim- A Female Beyond the Average Indian Womanhood in Anita Desai's Clear Light of Day
}

\author{
Arif Moin Uddin Khan \\ Assistant Professor, Department of English, Government City College \\ Chittagong-4000, Chittagong, Bangladesh
}

\begin{abstract}
Bim (Bimala) is the protagonist of Anita Desai's novel Clear Light of Day. Unlike the general Indian womenfolk, she is contemplative about her position and dares to fight against the traditional norms regarding females in Indian society. In doing so, she is not bothered about the consequences. Bim is highly sensitive and intelligent and endeavours to discover a relief from the sufferings created by the accepted notions of the society about women. In a sense, Bim is a feminist and somebody who surpasses the average Indian womanhood. This paper aims at examining the ways which make Bim a distinguished female character unmatched by most of her contemporaries in the society in which she lives.
\end{abstract}

Keywords: Traditional, norms, Indian society, feminist and womanhood.

DOI: $10.7176 /$ JLLL/56-03

Publication date:May $31^{\text {st }} 2019$

\section{Introduction}

Dealing emphatically with the feminine sensibility is an important aspect of Anita Desai's novels. The chief protagonists of her novels are female characters and her serious concern is with 'the journey within' of the female protagonists. The recurring theme of her novels is the agony of existence in a male-dominated society which is not only hostile to females but also conservative and taboo-ridden. However, the female protagonists fight against all odds and finally succeed to bring glory to their personality and add dignity to the spirit of freedom. Bim, the protagonist of Anita Desai's Clear Light of Day, is no exception to the fact stated above.

Anita Desai herself admits that her protagonists are new and different. She comments:

"I'm interested in characters who are not average but have retreated or been driven into some extremity of despair and so turned against, ... the general current." 1

\section{The Story in Brief}

The story of Clear Light of Day is about a Hindu family living in a rented house in Old Delhi. The novel centers round the mutual relationships of the four children of that Hindu family as they grow up to adulthood and then to middle age. The children are Raja, Bim, Tara and Baba who grow up in a household which offers a melancholic and unwholesome atmosphere because of the parents. The parents are indifferent to their children and are busy with their own affairs. A relative called Mira-masi (Aunt Mira) takes care of the children particularly of the child named Baba who is mentally retarded. In course of time, both of the parents die and so does Mira-masi. Raja leaves Old Delhi for Hyderabad and marries Benazir who is the daughter of their Muslim landlord Hyder Ali. Tara also gets married to a young man in the Indian foreign service and leaves for Ceylon or present Srilanka. In a word, Bim is left alone in the Old house in Old Delhi to look after her mentally retarded younger brother, Baba. Bim's deep concern for Baba, her satisfaction with the job of a lecturer in history in a college and her feminism pave the way for her growing to be a spinster.

\section{Bim Prepared Not To Be Average}

Bim was lucky enough not to be brought up to be diffident, meek and quiet in the face of deprivation. In fact, her parents being indifferent to her and her siblings proved to play a positive effect on Bim. As we know:

"Women in our society are still trained from infancy to entertain, to please and to serve men."

But Bim was fortunate. Her father was only known by his arrivals and exists and her mother through her diabetes and cards. As Shanta Acharya observes:

"Quite contrary to expectations, Bim's parents are both portrayed as remote and far removed from the world of their children. They are both noted by their absence, they do not influence the lives of their children in any significant way. The father seeks refuge in the club playing bridge, unable to cope with the twin horrors of a diabetic wife and a retarded child." 3 
So there was no chance for Bim to be taught the expected manners of the weaker sex. This fact paves the way for her to prepare herself in her own way.

\section{Bim- A 'New Woman' in the Perspective of Indian Society:}

Both Bim and Tara hail from the same Das family. But they represent two contradictory types of women. Tara is an ideal example of the general Indian women who do not act but surrender and thus let the tradition continue. On the contrary, Bim symbolizes the concept of 'New Woman' who does not surrender and is not meek but breaks the convention to meet challenges and chooses a new world where no one can dominate her. Bim desires to be independent and courageous and to dress and smoke like a man. This desire helps her to be strong and confident. As she has prepared herself not to be common, the most common qualities of women such as weakwill, dependence and submissiveness do not go with her personality.

Mr. Sharma who is the partner of Bim's father in the insurance business frequently wants that somebody from the Das family must attend the important meetings to be held at the office. At one point, Bim decides to sell the family share of the business to Mr. Sharma. In this regard, she sees no reason for consulting her sister's husband Bakul or her elder brother Raja. She has a firm confidence in modern woman's capacity to cope with all kinds of situations in life. She thinks that her students will laugh at her if they learn that she is finding it difficult to face the situation arisen in her late father's office.

Tara being a common woman considers it needless for Bim to buy books as books are available in the library of the college where Bim teaches. She thinks it better to spend more on food and less on books. But Bim does the opposite. According to her, food is the means of compensation for some people who miss something in life. Unlike general Indian women, she does not find satisfaction in the abundance of food in the family. She also does not support giving more importance on male child. Again, she does not support the way Indian women get their sons spoilt by treating them as prince whereas they regard their female children as burden.

\section{Bim- A Woman of a Strong Will :}

Bim is mentally very strong. The sudden death of her parents, the addiction of Mira-masi, the tuberculosis of Raja and mental retarding of Baba can not break her spirit. Even she does not feel helpless at Raja's desertion of her and Baba. She alone shoulders the responsibility of herself, Baba and also of her father's insurance business. She does not lose her courage. It seems that she makes us realize that a woman can look after the family in a much better way than a man if she has that degree of will. Bim's self-confidence makes her not to feel the necessity of protection or love from anyone. She does not like Mira-masi's yearning for love and protection. Mira-masi is happy to receive such things from the children if not from anybody else:

"They crowded about her so that they formed a ring, a protective railing about her. Now no one could approach, no threat, no menace... They owned her and yes, she wanted to be owned" (111)

But unlike Mira-masi, Bim does not want to be owned. She is a bright example of a contemporary Indian urban woman who is single, independent and self-assured. At a surface level, such woman may be considered 'westernized'. As Madhusudan Prasad comments, "This image combined with the image of Sisyphus, is replete with deeper symbolic significance. A momentous image, it is connected with the theme of the novel illuminating the real character of Bim." 4

In spite of many obstacles, Bim succeeds in materializing her desire. She is victorious in being independent, and it is Tara and Bakul who realize this:

"Bim had found everything she wanted in life. It seemed so incredible that she hadn't had to go anywhere to find it, that she had stayed on in the old house, taught in the old college, and yet it had given her everything she wanted. Isn't that strange Bakul.... . She did not find it - she made it, she made what she wanted." (158)

In Bim, we discover the emerging new and independent woman whom Simon de Beauvoir depicts:

"Once she ceases to be a parasite, the system based on her dependence crumbles; between her and the universe there is no longer any need for a masculine mediator." 5

Bim rightly presents herself as a woman of a strong self-confidence. She is independent and liberated. But their is no sign of arrogance or superiority in her. She is very clear about her aspirations. She is not the one who will roll in pity about her alienation.

\section{A female with Self-dignity:}

Raja marries Benazir who is the only child of their Muslim landlord Hyder Ali. Naturally, Raja and Benazir inherit all the property left by Hyder Ali including the house in which Bim and Baba continue living even after the death of their parents and Mira-masi, and Raja and Tara being separated from them. Raja writes a letter to Bim informing her that he and Benazir have decided not to increase the rent of the house. They have also agreed to let Bim and Baba continue to live in it on the original terms. Most of the women would be happy by 
considering this type of offer a great favour. But, Bim possessing a strong sense of self-dignity takes it as something insulting. She thinks that Raja behaves as if he were a big boss, and she and Baba were his dependants.

\section{A kind-hearted woman:}

Bim is like a coconut with a strict personality outwardly but inwardly she is a soft hearted person. So, she ultimately forgives Raja against whom she initially harbours a strong grievance for deserting her and Baba and also for writing a humiliating letter to her with a patronizing tone. Bim would have to forgive her parents also. She was resentful to them since she could not realize the disturbed condition of their lives.

\section{An Introspective Personality:}

Bim is an introspective kind of female. She has the ability to analyze her psyche. She tells Tara that, whenever passing close to the well, she feels that she sees Mira-masi. Then Bim turns her head very quickly to have a better look but just at the moment Mira-masi vanishes. On such occasions, she feels like one of those Antarctic explorers T.S. Eliot has written about in his notes to The Waste Land:

Who is the third who walks always beside you?

When I count, there are only you and I together

But when I look ahead up the white road

There is always another one walking beside you

Gliding wrapt in a brown mantle, hooded

I don not know whether a man or a woman

- But who is that on the other side of you? (41)

Only a person having the quality of introspection can present her inner self in the way stated above.

\section{A Woman Not Accepting Marriage as the Most Important Task:}

Bim tells Tara that she can not understand the reason why Misra sisters are getting married instead of going to college and completing their education. Tara replies that the girls' mother herself got married at the age of twelve and now she wants them to be married soon as they are already sixteen and seventeen years respectively. Bim comments that the girls are foolish to agree to get married before being properly educated and acquiring any academic degree. At Tara's disapproval of what she has said, Bim feels irritated and says that a girl can do hundreds of things before her marriage. Giving her own example, Bim says that she will never get married and will never leave Baba, Raja and Mira-masi. She says, 'I shall work- I shall do things, I shall earn my own livingand look after Mira-masi and Baba and - and be independent. There'll be so many things to do- when we are grown up- when all this is over-' $(140 \& 141)$

\section{A Character with the Praiseworthy Analytical Ability:}

Raja writes a letter to Tara inviting her to Hyderabad and she reads it out to Bim. Bim has not even been mentioned in that letter; nor has Raja written any letter to her separately. Bim clearly realizes that Raja is now valuing Tara whom he has always ignored. On the contrary, Bim has no importance to him. She is surprised at this devaluation of herself by Raja. Then she wonders whether she has any value at all for anybody in the family. Then she discovers a brilliant analogy between herself and a family heirloom. A family heirloom, as Bim thinks, is neither valuable nor beautiful but is considered being precious based on its long age and its family standing. However, she regards herself as being less precious than an heirloom. She considers herself valueless even to Baba who takes no notice of her existence. In fact, he is unaware of her existence both in his waking hours and in his sleeping. Bim appears to go unnoticed by Baba whether she is happy or sad, grey or young. Bim thinks that, even if she were to vanish, or if the waters of Jumna were carry her off, Baba would not know it. All these thoughts of Bim are the proofs of the keen analytical ability possessed by her.

\section{A Dedicated Soul to Profession:}

Bim could have avoided the pains of inviting a few of her students to come to her house to discuss some topics which had not fully been discussed in the classroom in the course of her regular lectures and seminars. But she did not do so. It shows her sincerity and a deep sense of responsibility. But, a good number of employed women in the society lack this type of dedication to profession shown by Bim. They put less emphasis on their job than their domestic affairs. They are usually engaged in job not for establishing their personal identity and self-dignity but for earning. So, they can not enjoy their profession. Again, the organizations for which they work are deprived of the best possible service of them. Unlike these women, Bim is providing a wholehearted service to the students, that is, to the college in which she works. Thus she is benefiting her working place in the best possible way. 


\section{A Person with Refined Taste:}

Bim is a student of history. But she does show a genuine interest in the works by Byron, Swinburne and T.S Eliot of English literature. She also has knowledge about the works of Ikbal who is a great poet of Urdu language. If her desire was only to gain academic excellence, she could confine her study to the study of history only. But she did not do so. In fact, she is not an average Indian female devoid of thirst for knowledge.

\section{A Real Heroine:}

Usually a heroine does not sacrifice her marital life for the sake of her career on the screen. Bim who expresses her desire to be a heroine on the screen can not be so in later life. But she becomes the real heroine in her practical course of life by sacrificing her marriage for the cause of her mentally retarded brother Baba. Thus she shows her being a female character beyond the average Indian Womanhood.

In her life, she did not depend on anyone, not even on her father. If she depended on her father for her education, she would be an illiterate. She says:

"for all father cared, I could have grown up illiterate-

and cooked for my living or swept. So I had to teach myself

history and teach myself to teach." (155)

Here again Bim proves to be a real heroine surviving all the challenges within the house and outside.

\section{Conclusion:}

Like ordinary Indian women, marrying and having husband, and giving birth to children to ensure future generation and dying after leading a common life is not the most important philosophy of life for Bim. She looks at life from a much broader perspective and feels the urge to accomplish more responsible works than the ones mentioned above.

Being employed, Bim achieves financial freedom. We may say that Anita Desai, through Bim, wants to mean that economic independence can enable women to protect themselves from the violence and oppression exercised on them by the males. In this regard, the words of R.K Srivastava are quotable:

"The man-woman relationship becomes more important due to rapid industrialization, growing awareness among women of their rights and individualities, and westernization of attitudes and lives of the people." 6

Bim heralds a new age for the women in the coming days. She challenges the restrictions regarding her position within the family and society. Receiving education, being independent both emotionally and economically, she totally rejects the established idea of upper middle-class women as passive , compliant and conservative wives-to-be. Thus she triumphs to present herself as a female personality transcending the traditional concept of average Indian womanhood. She is an ideal for those women who do not want to be subservient to men but want to live on themselves with their own identity regardless of being single or married. It may be said that Bim possesses the qualities of a feminist.

\section{References}

1. Dalmia, Yashodhara, 'An Interview with Anita Desai', The Times of India. April 29, 1999, 13 Quoted in 'Introduction' Perspectives on Anita Desai, ed. Ramesh K. Srivastava, Vimal Prakashan, Ghaziabad, 1084, p. XXXIII.

2. Cooke, Joanne, 'Here's to you, Mrs. Robinson: 'An Introduction' The New Woman: A Motive Anthology on Women's Libbers (ed. Joanne Cooke, Robin Morgan et al. Fawcett Book, 1970), p. 16.

3. Acharya, Shanta. "The Problems of the Self in The Novels of Anita Desai" in R.K. Dhawan (ed.) Explorations in Modern Indo-English Fiction. (New Dellhi: Bahri, 1982).

4. Prasad, Madhusudan, "The Novels of Anita Desai: A Study in Imagery, p. 75."

5. Beauvoir, Simon de, The Second Sex, p. 412.

6. Srivastava, Ramesh Kr., "Perspectives on Anita Deasi” published by Vimal Prakashan, Ghaziabad, 1984, p. XXVI. 